\author{
Asian Journal of Economic Modelling \\ $\operatorname{ISSN}(e): \quad 2312-3656$ \\ $\operatorname{ISSN}(p): \quad 2313-2884$ \\ DOI: $10.18488 /$ journal.8.2014.22.93.102 \\ Vol. 2, No. 2, 93-102 \\ (C) 2014 AESS Publications. All Rights Reserved. \\ URL: www.aessweb.com
}

\title{
COPING WITH INFORMALITY AND ILLEGALITY: THE CASE OF STREET ENTREPRENEURS OF HARARE METROPOLITAN, ZIMBABWE
}

Tavonga Njaya

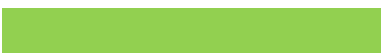

Faculty of Commerce and Law, Zimbabwe Open University, Zimbabwe.

\section{Article History \\ Received: $\operatorname{xxxxxxxxx}$ \\ Revised: $\mathrm{xxxxxx \times xx}$ \\ Accepted: $\mathrm{xxxx \times x \times xx}$ \\ Published: $\operatorname{xxxxxxxx}$}

\section{Keywords}

Coping

Informal economy

Informality

Illegality

Public urban space

Street vendor.

\begin{abstract}
The study sought to examine how street vendors were coping with informality and illegality in metropolitan Harare. Data collection techniques included in-depth personal interviews, direct observations and documentary reviews. A semi-structured questionnaire was used to collect socio-economic and technical data pertaining to street vending and the resistance strategies adopted by the vendors. The study showed that despite numerous constraints placed on various groups of street traders, these groups had actually developed survival and resistance strategies that enabled them to maintain their livelihoods from public urban space. These strategies included "soft" forms of resistance; small-scale individual and group actions; subtle and innovative arrangements and even open protest and direct confrontation with the authorities. This was because for many street vendors, the street provided them with an honourable and respectable means of livelihoods. The study recommended that the government should recognise street industry through registration and introduction of a code of practice for street vendors. Over time a legal instrument should be introduced to regulate the operations of street traders. However, as a first step towards recognition, street vendors should constitute themselves into well organised associations that could become a forum of negotiations with the City of Harare. Future research should focus on quantifying the number of street vendors in Harare and their economic benefits.
\end{abstract}

Contribution/ Originality: The paper contributes the first logical analysis of individual and group strategies used by street vendors to cope with informality and illegality. Street vendors do not have right to employment and as such are usually evicted from open urban spaces. 


\section{INTRODUCTION}

The term "informal" was coined by Keith (Hart, 1973) while the concept of "informal sector" was first used by the International Labour Organisation in 1972 (Sindzigre, 2006).Sinha and Kanbur (2012) have noted that despite the misuse of the terms "formal" and "informal" within the policy circles, they have survived and even thrived in the development discourse. In particular, informality has persisted in this discourse because of the strong association between informality and poverty and because of an explicit or implicit presumption of many development theories that informality will pale into insignificance as development proceeds (Sinha and Kanbur, 2012). Informal sector refers to unregulated labour-intensive activities, self-employed entrepreneurs, micro and small enterprises, activities that take place outside state regulations or formal firms, unregistered activities or which include various degrees of illegality such as escaping taxation, non-compliance with labour regulations, financial transactions outside the monitoring of the state or banks (from capital flight to petty village money lenders) and smuggling (Sindzigre, 2006). Sinha and Kanbur (2012) characterised the informal sector broadly as consisting of units engaged in the production of goods and services operating typically at a low level of organisation with little or no division between labour and capital as factors of production (also an extensive blurring between labour and management or ownership) and on a small scale.

Street vendors are part of an extremely visible category of informal workers who invariably escape compliance with state regulations of their business enterprises. Although street vendors have occupied the streets of Harare en-masse, their activities and motivations have remained poorly understood (Njaya, 2014). Meanwhile, legislation, regulation and enforcement have constantly failed to reflect the changing circumstances and incorporate them into town planning to ensure sustainability of street vending and hence its contribution to sustainable development of the country. The City of Harare has responded to the challenges brought about by street vending by evicting street vendors en-masse. Njaya (2014) noted that despite these violent evictions, street traders continued to occupy new locations and to operate outside the bounds of the law. This was because street entrepreneurs devised strategies of evading compliance with state regulations of their street businesses. In the literature, street vendors have used various resistance strategies including "quiet" forms of resistance; small-scale individual actions; subtle and innovative arrangements and sometimes open protest and direct confrontation (Bromley, 2000; Crossa, 2009; Lindell, 2010). In this study, the term street vendor includes stationary or static vendors who occupy public urban space: pavements, roads, parks, and alleyways using temporary stalls.

\subsection{Statement of the Problem}

Although street vendors have occupied the streets of Harare en-masse, their activities and motivations have remained poorly understood. In the absence of a law to protect their right to livelihood, street vendors in Harare, had to hawk their goods illegally which made them more vulnerable. As a result the street traders became targets of harassment by both the municipal and national police. What challenges are faced by street vendors? How are street vendors coping with informality and illegality in Harare? These were the overarching issues addressed in the study. 


\subsection{Study Objectives}

The study's primary aim was to explore strategies employed by street vendors in order to cope with informality in Harare. The specific objectives of the study were:

- To describe the nature of street vending in Harare.

- To identify problems faced by street vendors in Harare.

- To identify strategies employed by street vendors in order to cope with informality and illegality in Harare.

\subsection{Research Questions}

- What is the nature of street vending in Harare?

- What are the problems faced by street vendors?

- What are the strategies employed by street vendors to cope with informality and illegality in Harare?

\section{STUDY METHODOLOGY AND DESIGN}

The study used qualitative approach (Bryman, 2001). The population of the study included all street vendors in Harare. The City of Harare was purposively selected for the study because the City experienced the highest proliferation of street vendors in Zimbabwe (Njaya, 2014). During the 2012 census, Harare recorded the highest population of 16.2 percent (ZIMSTAT Zimbabwe National Statistics Agency), 2012). Data collection techniques included interviews, observations and document reviews. A semi-structured questionnaire based on the study's objectives (Bryman, 2001) was used as the basic tool to collect data pertaining to street vending and resistance strategies used by the street vendors. Closed-ended questions enabled the researcher to ask standardised questions and to collect uniform data from the selected vendors while open-ended questions were used to explore the current situation of street vending in Harare.

\section{DISCUSSION OF RESEARCH FINDINGS}

The questionnaire was structured to find out the forms or modalities of street vending; risks faced by street vendors and resistance strategies employed by the street traders in order to retain public urban space in Harare.

\subsection{Forms of Street Traders in Harare}

Street vending varies in terms of scale, timing, location, remuneration, workforce and type of goods sold and services provided (Bromley, 2000). That is, it can be full time occupation, a parttime occupation, seasonal or occasional and can be carried out by one person, family or franchise of a large street business. Harare experienced an enormous growth in street vending over the last decade with vendors selling everything from fresh food and medical drugs to mobile phones and mobile recharge cards, electrical gadgets ( $\mathrm{TV}$ sets, stereos), cars, bricks and river sand. Meanwhile other vendors provided services on the streets and predominant among them included haircut, hair plaiting, manicure and pedicure, car wash, bicycle repair, cell phone unlocking and installation of internet and WhatsApp on cell phones and mending. Street vendors were observed 
in most public and private places including industrial and construction sites, hospitals, schools, sporting stadia, bus termini, church buildings, shopping and commercial centres, pavements, sidewalks, alleyways, open spaces and along virtually every street of Harare's suburbs as well as the central business district. The major categories of street vendors observed included mobile, stationary, fixed and itinerant vendors. The facilities used included kiosks, open spaces, wooden or canvas or polythene stalls, hawker's kiosks, push carts, cycles, collapsible stands, semi-fixed stalls such as folding tables, crates, trucks, vehicles and vans with specific food service equipment. The selling of merchandise from car boots was becoming a common phenomenon in Harare especially during weekends. Organised car boot sales were usually conducted as fundraising activities by schools and church organisations where individuals came together to sell old as well as new goods. In the case of street food vending, Njaya (2014) observed that the equipment used included baskets, plastic boxes, firewood braziers, gas stoves, braai stands, cooler boxes, plastic buckets and refrigerators while cooking utensils observed included pots and pans (usually black which are suitable for use on fire, spoons, (wooden and metal), plates (metal and plastic), knives, cups (metal and plastic), dishes or bowls (metal and plastic).

\subsection{Formality and Regulation of Street Vending in Harare}

Street vending is illegal in Harare and Zimbabwe as a whole. Vending is only allowed in designated areas for example in flea markets. According to Njaya (2014) more than 98 percent of the street vendors were operating illegally in Harare. Instead, the City issued hawker's licenses which included a restriction on the type of food sold (vegetables) and the location where they could be sold. Vending of cooked foods was governed by the Public Health Act, Chapter 15.09 and the Food and Food Standard Act, Chapter 15.04. As already observed by Njaya (2014), these two pieces of legislation have origins in colonialism and were designed to protect established businesses (mostly white) while subjecting small businesses (mostly owned by blacks) to harassment for failure to meet prescribed standards. Harare (Hawkers) By-laws 2013 state that "...no person shall engage another to carry the business of hawking unless he or she is in possession of a valid hawker's employers' license.” The license costs US $\$ 120$ per annum and must specify the number of hawkers that the holder may employ or retain as an agent. The regulations stipulate that no hawker shall remain stationary while conducting his or her business for more than 15 minutes. The by-laws also state that the Council may refuse to issue or renew a hawker's license if in its opinion, "...the issue of renewal would adversely affect any existing trade or businesses carried out in the area." These by-laws seemed to anti-street vendors from poor backgrounds. Instead, they were designed to regulate street vending by established businesses that sold their products through mobile hawkers such as Dairibord Zimbabwe (ice cream, milk, yoghurt and juice); Alpha Omega Dairy (ice cream, milk and yoghurt) and Delta (maheu and fizzy drinks).

Although it is exceedingly difficult to produce accurate estimates of the number of street vendors in Harare, Njaya (2014) observed that their number had significantly increased over the last decade. In fact, from mid-1990s Zimbabwe witnessed a deepening process of informalisation as a growing number of urban dwellers relied on economic activities outside state regulations. 
The "ill-devised" economic structural adjustment programme, 1990-1995 ignored local conditions and dismantled public services which drove thousands of people into the informal economy. Njaya (2014) attributed the rise in the number of street traders to rural-urban migration of low skilled workers towards cities, redundancies caused by the worsening economic crisis and lack of employment opportunities in the formal sector. The rise in the number of street traders was not unique to Zimbabwe. Carr and Chen (2002) observed that the number of street vendors had been increasing worldwide. The growing number of people depending on street commerce often intensified tensions between street entrepreneurs and the City of Harare. The street vendors wanted to eke a living from public urban space. The City of Harare on the other hand, due to the influence of neoliberal urban planning is exposed to international competition under "the world class city status". Lindell (2010) observed that city beautification measures and clearance exercises had multiplied across cities in Africa and beyond. On the domestic front, the City was exposed to pressures of investors to keep the city clean. In order to uphold a modern city image, City of Harare adopted interventions that had direct negative effects on the livelihoods of urban street entrepreneurs. Consequently, police raids and evictions of street traders became increasingly frequent. According to Bromley (2000) street vending is closely connected with the availability of public urban space: pavements, roads, parks, beaches etcetera and many of the difficulties associated to the activity including the generally negative way it is perceived by the wider society are linked to the ways in which such spaces are managed by the authorities.

\subsection{Problems Faced by Street Vendors in Harare}

Generally, street vendors operated outside the bounds of law, without permits or license or standard infrastructure supported by the City of Harare. As a result, street vendors, more often that not faced significant challenges in carrying out their livelihood-sustaining activities. The following were listed by the street vendors as the major problems they faced when operating street enterprises:

- $\quad$ raids and confiscations of their merchandise by both the national and municipal police

- $\quad$ difficulties of having to be on constant lookout for police and thieves

- $\quad$ arduous and sometimes precarious work

- $\quad$ long working hours

- $\quad$ perpetual boredom

- $\quad$ sweeping streets and setting up vending stands everyday

- $\quad$ competition from new entrants

- $\quad$ negative perception from the wider society

- $\quad$ harassment and exploitation by municipal authorities

- $\quad$ inadequate or lack of social protection

- $\quad$ lack of public utilities (roads, electricity, toilets, potable water and waste disposal)

- $\quad$ lack of organisational strength and voice

- lack of dignity

- lack of right to work

- demand of bribes by municipal and/or national police 
- $\quad$ rough weather (sun, heat, rain and cold)

- $\quad$ lift and haul heavy loads of merchandise to and from vending sites everyday

Generally speaking, street vendors' legal status could act as a bridge between their employment conditions and the range of employment risks they faced (Njaya (2014). Meanwhile, a vendor with a fixed structure in a designated market, for example, was more likely to hold a license and in turn could be less exposed to certain kinds of the above risks. Likewise, a street vendor who worked as an employee selling a particular kind of product such as newspapers or ice cream was better protected by the law and therefore less vulnerable. Unfortunately a majority of the street vendors had to cope with informality and illegality. However remaining on the streets involved high costs of insecurity and evictions though the benefits of street selling were compelling to the street entrepreneurs. The next subsection presents resistance strategies employed by the street vendors in order to retain their vending sites.

\subsection{Coping with Informality in Metropolitan Harare}

Because of the problems of congestion, safety, health and environment which have unfortunately overshadowed the significant contribution of street vending to the economy, street vendors have become targets of harassment and persecution by both the municipal and national police. According to Bromley (2000) street vendors face a complex coexistence of persecution, regulation, tolerance and promotion. Despite the violent evictions, Njaya (2014) observed that street sellers continued to occupy new locations and to operate outside the bounds of the law. As a result, street vendors devised various strategies in order to cope with informality and noncompliance of their street enterprises with municipal by-laws and regulations. This was because for many street vendors, the street provided them with an honourable and respectable means of livelihoods.

One strategy which was very common was the use of a square sheet. The vendors would put merchandise on a blanket or cloth or plastic sheet or canvas either on the ground or makeshift counter made of cardboard boxes. In the event of a police raid, the vendors would quickly grab the four corners of the blanket or plastic and run to safety. For some vendors the sheet had cords attached to the corners such that in the event of police raids, the vendor would grab the cords to pull their merchandise into a ball or bag and easily make a run of it. This strategy had become very common in Harare's central business district (CBD) as the sheet had dual purpose of displaying and carrying merchandise to and from vending sites.

The second strategy involved street entrepreneurs vending in the CBD around 5pm after municipal police finished work for the day. After $5 \mathrm{pm}$ the number of street vendors would begin to swell and the groups begin to enjoy the freedom of controlling public urban space as they made sales uninterrupted by police raids. Most street pavements in the CBD became barricaded with different merchandise including fruits, meat (beef, pork and chicken), fish, vegetables, clothes, furniture items such as ironing boards, stools and push trays, mobile phones and recharge cards, pirated audio and visual CDs and footwear. Most vendors were concentrated around commuter pick-up and drop-down zones of Market Square, Copacabana, Harare Central Police Station, Rezende and Fourth Streets where workers would do their shopping on their way back home. 
The third coping strategy was the use of safe places or "strategic bases" to keep merchandise awaiting sale. These safe places included offices, licensed shop parcel counters, storm drains, alleyways and vehicle parking lots. The vendors paid a certain fee to the security guards where merchandise was stored in offices or behind licensed shop premises. Sometimes the vendors displayed dummy goods on the street and kept genuine products in the safe places. After identifying a customer the vendor would collect the genuine product from the safe place. Usually the safe warehouse would be within the proximity of the vending site.

In the absence of a law protecting their right to livelihood, the vendors had to hawk their goods illegally which made them more vulnerable. Regular police raids of street vendors had created opportunities for rent-seeking or outright corruption. Sometimes vendors paid bribes to municipal police to avoid confiscation of merchandise or to have their merchandise released from council custody. Sometimes the vendors paid protection fees. These fees were paid on a regular basis and were meant to ensure that the vendors were spared of the raids or were warned in advance of impending raids. The bribes or protection fees usually ranged between US $\$ 2$ and $\$ 10$ depending on the type of merchandise being sold. For example, Peter sells mobile phone accessories in the CBD and paid US20 every week to municipal police as protection fee.

If I don't pay the protection fee, the municipal police would destroy my stall and confiscate all my merchandise. I have a wife and a child to look after. I don't have any other means of livelihoods except the street.

But how serious or pervasive was the problem of street vendors being asked to pay bribes or protection fees in Harare? The severity of the problem can be gauged from the fact that there was not a single street vendor in the sample who did not pay bribes or protection fees. In addition, in most of the raids the vendors were able to flee with their merchandise without a problem and arrests became rare. However, to the street vendors, paying bribes had become a norm and did not mind as long as such payment(s) guaranteed an uninterrupted sale of their merchandise.

Street vendors' resistance strategies sometimes extended into formal political spheres. This entailed groups of street traders seeking leverage with prominent politician(s) or political party in order to retain their vending sites. During the fieldwork, I was informed that vendors in some unlicensed flea markets in the $\mathrm{CBD}$ were never raided by the municipal or national police because they were aligned to the ruling party, ZANU-PF. According to the street vendors in the sample, the allocation of tables in such flea markets was partisan.

Besides resisting removal from the streets, some street vendors established mutual informal associations with shop owners. Under such subtle agreements, the shop owners and vendors agreed to share electricity and water bills as well as the sweeping of the streets. Sometimes the shop owners provided refuge or sanctuary to vendors' merchandise in the event of police raids and even stored the goods overnight. In return the street vendors sometimes agreed to sell products on the street on behalf of the shop owners. In Mexico, Crossa (2009) noted that such informal associations between street vendors and shop owners actually boosted sales of licensed shops. In Harare, I was informed that, the practice had the potential to encourage thieves to masquerade as vendors and as a result very few shop owners were willing to have vendors selling their products within shop premises. Nevertheless, shop owners selling computer and mobile 
phone accessories preferred such arrangements as they brought their products closer to the customers and hence boosted their sales.

Spontaneous whistling was another resistance strategy employed by street vendors in Harare. Under this strategy, each street vendor acted as a "watchman or watchwoman". The early warning system allowed vendors to pack their merchandise and flee before the police could catch them. Sometimes the vendors used a queer noise or cry to alert fellow vendors of police presence.

Open and direct confrontation with the police, though at reduced scale was another strategy of resistance used by the street vendors to retain their vending sites. Violent street confrontations have been a resistance mechanism throughout much of the history of street vending activities (Crossa, 2009). According to Crossa (2009), street battles between police and street vendors and sometimes fatal were quite common in Mexico. In Harare the vendors clashed with the national police in January 2012, when the latter tried to dismantle street vendors' stalls along Nelson Mandela Street in the CBD. According to The Herald (2012) the national police were called in by the City of Harare to help clear the pavements in the CBD. In the ensuing running battles, one police officer was attacked and injured by the vendors. Six street traders were subsequently arrested. But where did the street vendors' determination to confront the national police come from? It would appear the major reason had an economic dimension: eviction from the street endangered street vendors' economic niche in the City. Meanwhile others insinuated a political motive behind the police's crackdown of street vendors along Nelson Mandela Street. Because the headquarters of the Movement for Democratic Change-Tsvangirai (MDC-T) are along this road it was suspected that a majority of the street vendors were political activists of the party. Accordingly, the police raid was meant to destroy the livelihoods of vendors aligned to the MDC$\mathrm{T}$.

Besides the above, street vendors also engaged in a range of other resistance strategies which included:

- mobile vending where the vendors sold their merchandise in baskets, trays, bags or plastic bags

- $\quad$ selling merchandise from a car's boot

- selling merchandise from their pockets or attached to their bodies

- rotating between two or among more sites taking advantage of different types of clientele and different patterns of urban movement over the course of the day.

Would street traders' resistance strategies endure? During the fieldwork, I observed that the authorities' objective to rid the City of street vending was encountering serious challenges. Through individual and collective everyday actions, street vendors had not only resisted but had also "conquered" new public urban spaces (particularly the CBD) and in the process seriously undermined the capacity of the authorities to exercise surveillance. Prior to 2000 there was no significant vending in the CBD except for street vendors who worked as employees selling newspapers and ice cream. Diminishing jobs in the formal sector, rural-urban migration and overall population growth were the major reasons behind rising number of street entrepreneurs in metropolitan Harare. 


\section{CONCLUSION AND RECOMMENDATIONS}

The study showed that despite numerous constraints placed on various groups of street traders, these groups had actually developed individual and collective survival and resistance strategies that enabled them to maintain their livelihoods from public urban space. The street vendors' resistance over the City's by-laws was more than a territorial struggle, but rather a struggle over their rights as citizens to public urban space and economic activity. The business of street vending needs to be addressed carefully in order to derive maximum benefits for the entire economy. Generally, there is need to integrate the street economy into the mainstream economy in a way that would ensure sustainability of the former and long-term economic growth and sustainable development of the country. Future research should focus on quantifying the number of street vendors in metropolitan Harare and their economic benefits.

Thus, recognising the fact that street vending had become a permanent phenomenon in Zimbabwe, I made the following recommendations;

- The City of Harare should recognise street commerce through registration and licensing.

- As a first step towards recognition, street vendors should constitute themselves into well organised associations which would enable them to develop code of practice for their businesses or constitute a forum for interaction with the City of Harare.

- The City should allow vendors to set up temporary market stalls from $5 \mathrm{pm}$ to say $10 \mathrm{pm}$ in some designated streets which would be closed to all traffic.

- Non-governmental organisations and vendors should start regular consultations to coordinate advocacy programmes with a view to recognition and formalisation of street vending.

- The City of Harare should construct decent shelters or vending kiosks which can be rented by street vendors.

\section{REFERENCES}

Bromley, R., 2000. Street vending and public policy: A global review. International Journal of Sociology and Social Policy, 20(1-2): 1-19. Available from http://wiego.org/publications/street-vending-andpublic-policyglobalreviewinternationaljournal-sociology-and-socia [Accessed 4 April, 2014] .

Bryman, A.E., 2001. Social research methods. Oxford: Oxford University Press.

Carr, M. and M.A. Chen, 2002. Globalisation and the informal economy: How global trade and investment impact on the working poor. Geneva: International Labour Organisation. Available from http://www.ilo.org/wcmsp5/groups/public/_-ed_emp/documents/publication/wcms_122053.pdf [ Accessed 4 April 2014].

Crossa, V., 2009. Resisting the entrepreneurial city: Street vendors' struggle in Mexico city's historic centre. International Journal of Urban and Regional Research, 33(1): 43-63. [Accessed 4 April 2014]. DOI 10.1111/j.1468-2427.2008.00823.x.

Hart, K., 1973. Informal income opportunities and urban employment in Ghana. The Journal of Modern African Studies, 11(1): 61-89. DOI http://dx.doi.org/10.1017/S0022278x00008089. 
Lindell, I., 2010. Between exit and voice: Informality and the spaces of popular agency. African Studies Quarterly, 11(2\&3): 1-11. Available from http://www.africa.ufl.edu/asq/v11i2-3a1.pdf [Accessed 5 May 2014].

Njaya, T., 2014. Nature, operations and socio-economic features of street food entrepreneurs of Harare,

Zimbabwe: IOSR Journal of Humanities and Social Science, 19(4): 49-58. Available from http://www.iosrjournals.org/iosr-jhss/papers/Vol19-issue4/Version-3/Ho19434958.pdf

[Accessed 21 April 2014].

Sindzigre, A., 2006. The relevance of the concepts of formality and informality: A theoretical appraisal in Guha Khasnobis, B., Kanbur, R. and Ostrom, E., (eds). Linking the formal and informal economy: Concepts and policies. Oxford: Oxford University Press.

Sinha, A. and R. Kanbur, 2012. Informality: Concepts, facts and models. The Journal of Applied Economic Research, Special Issue of Marginal: 1-11. Available from http://www.kanbur.dyson.cornell.edu/papers/Informality-

Concepts,\%20Facts\%20and\%20Models.pdf [Accessed 4 May 2014].

The Herald, 2012. Police, vendors clash could have been avoided. January, 12, 2012. Available from http://www.herald.co.zw/police-vendors-clash-could-have-been-avoided/ [Accessed 6 May 2014 ].

ZIMSTAT Zimbabwe National Statistics Agency), 2012. Census 2012 preliminary report. Harare: ZIMSTAT. 